Бојан Јовић

Институт за књижевност и уметност, Београд userx64@live.com

https://doi.org/10.18485/ai_godine_ww1.2019.ch14

7.044(497.11)"1914/1918"

82(497.11)"1914/1918"

94(497.11)"1914/1918"

\title{
ПРВИ СВЕТСКИ РАТ - НЕКИ ЕСТЕТИЧКИ И ПОЕТИЧКИ АСПЕКТИ ${ }^{1}$
}

Ancтракт: У тексту ће се указати на неке од најупечатљивијих примера преплитања и прожимања поетичких, естетичких, идеолошких политичких и начела са непосредним војним активностима, оличених у стварању и деловању истакнутих писаца и уметника током Првог светског рата. Пажња је посвећена критичком преиспитивању односа према стварности, од преовлађујућег става да ће рат препородити на смрт болесну грађанску цивилизацију са почетка XX века, преко стварања хибридних пропагандно-уметничких дела, преко улоге лика и личности Чарлија Чаплина и његових филмова у ратном напору, који уз естетску доносе и димензију хумора и смеха, до непосредне примене уметничких техника у стварању и развитку камуфлаже.

Клучне речи: Велики рат, естетика, авангарда, манифести, камуфлажа, Чарли Чаплин

Захваљујући значајном броју истакнутих стваралаца који су, активно учествујући у Првом светском рату, преточили доживљена искуства у уметност, истовре-

1 Рад је настао у оквиру научног пројекта Института за књижевност и уметност из Београда ON178008 Српска книжевност у европском културном контексту, који финансира Министарство просвете, науке и технолошког развоја Републике Србије. 
мено је (пре)обликујући на садржинском и на формалном плану у складу са новом ратном реалношћу, може се тврдити да Велики рат представља један од најважнијих епохалних поетичких и естетичких чинилаца. ${ }^{2}$ Однос књижевног и уметничког стваралаштва - пре свега авангардног - и Великог рата, међутим, није искључиво једносмеран и последичан, већ је на битан начин двосмеран и проактиван, како на манифестном тако и на конкретно уметничком плану; захваљујући тој чињеници, широки распон деловања писаца и уметника довео је до појаве нарочитог укрштања и хибридизације рата и уметности, односно до милитаризације уметности и естетизације рата, појаве која је у први план ставила пре свега проблематизацију стварности кроз разарање, прикривање и преобликовање представа о њој.

Са становишта радикалних европских уметничких покрета и усмерења са почетка XX века, Први светски рат се показује као остварење идеја исказаних у програмским, манифестним, односно експлицитнопоетичким текстовима. ${ }^{3}$ Пре свега, уметници оновремену (над)националну грађанску цивилизацију по правилу доживљавају као одрођену и болесну а њене културне

2 Тим више што је, осим на тематику и обликовање, утицао и на стварање и динамику ширих уметничких феномена. Примера ради, као непосредна последица ратних збивања, током 1916. настаје изворни авангардни антиратни покрет - дадаизам, окупивши у неутралној Швајцарској уметнике из Немачке и Румуније, Холандије и Швајцарске. Први светски рат је непосредно условио и стварање југословенске књижевности, као и првог таласа српске послератног модернизма / авангарде.

3 Најшири идеолошки разлози за прихватање рата код европских се стваралаца подударају се и преплићу са естетским, садржаним у кључним особинама авангардног доживљаја стварности као што су брзина, агресија, фрагментација или разарање (опажања / представљања) стварности, интензитет догађања и сензација, узбуђења борби и присуства смрти, патриотизма, братства и (мушког) херојства. 
и уметничке установе и облике као мртве; разарање и рат у том се схватању виде као коначна средства за њихово (про)чишћење и излечење. У оснивачком манифесту италијанског футуризма из 1909. године, вођа покрета Ф.Т. Маринети жели да ослободи Италију од гангрене коју види у професорима, археолозима, туристичким водичима и старинарима, изједначавајући музеје, библиотеке и академије са гробљима (Маринети 1909); у деветом поглављу Маринети изјављује да ће футуристи славити рат као једину хигијену света, уз милитаризам, патриотизам, разорне чинове анархиста и прелепе идеје за које вреди умрети. (Иcmo) Пет година касније, по избијању непријатељстава у Европи, у прогласу италијанским студентима насловљеном "У овој футуристичкој години" залажући се да се Италија укључи у сукоб, Маринети развија своје тезе о нераскидивој повезаности футуризма, војних дејстава и уметничког стваралаштва, тврдећи да појава футуризма означава избијање рата у уметности/.../: "динамички и агресивни футуризам данас се потпуно остварује у великом светском рату, кога је футуризам - једино он предвидео и славио још пре и него што је избио.“ (Маринети 1914) Рат се показује као основа уметничког надахнућа, носилац напретка која повећава интелигенцију, обогаћује, унапређује и испуњава живот појединца и јача његову везу са домовином. ${ }^{4}$ У футуристичком

4 "Ми, слободноречари, сликари, музичари, архитекте, и звучари, смо одувек сматрали да је рат једино надахнуће уметности, једино морално чишћење, јединствени квасац за људско тесто. Једино рат зна како да подмлади, убрза, изоштри људску памет, олакша и проветри живце, ослободи их свакодневних оптерећења, подари животу хиљаду укуса а имбецилима генијалност. Рат је једино закрилце новог аеропланског живота који припремамо. Рат, појачани футуризам, никада неће убити рат, како се пасеисти надају, али ће убити пасеизам. Рат је највиша и савршена синтеза напретка (агресивна брзина + насилно појед- 
виђењу уметности и стварности, Први светски рат се, на крају, недвосмислено одређује као врхунско уметничко дело: „Садашњи рат јесте најлепша футуристичка поема која се до сада појавила“. (Исто) У складу са тим, у манифесту „За рат, једину хигијену света“ дословно понављајући ставове изнесене четири године раније у «Италијанском Триполију», Маринети позива на потпуну обуставу уобичајене књижевне и уметничке делатности и "стваралачки" приступ рату, у коме бука шрапнела образује симфоније а артиљерија «луде скулптуре» у непријатељској живој сили. ${ }^{5}$ У овом случају, међутим, футуризам остварује оно што заговара - манифест се завршава речима да је футуристички књижевни, ликовно-музички покрет «тренутно обустављен» због одсуства песника Маринетија који је отишао на ратиште.

Идеје о рату као прочишћењу оболеле цивилизације и средству за стварање нове, боље људске заједнице, односно као о посебној стварности - уметничком делу, заступљене су и код уметника на другим фронтовима. У првим ратним месецима, у забелешкама и писмима са француског бојишта, немачки експресиониста Франц Марк изражава задовољство због избијања оружаног сукоба и изражава мишљење да је рат страшан али неопходан лек - крвна жртва - на путу очишћења и припреме Европе за ново доба. ${ }^{6}$ Варирајући своје идеје бо-

ностављење напора ка благостању). Рат је муњевито наметање храбрости, енергије и интелигенције свима. Обавезна школа амбиција и јунаштва; пуноћа живота и максималне слободе у посвећености домовини." (Маринети 1914)

5 „Песници, вајари и музичари, футуристи Италије! Све док рат траје, оставимо по страни стихове, четкице, длета и оркестре. Почели су црвени празници генија! Данас се можемо дивити само силној симфонији шрапнела и лудим скулптурама које наша надахнута артиљерија обликује у непријатељским масама.“ (Маринети 1915)

6 „Ја, пак, живим у овом рату. Чак га видим као лековит, иако страшан, прелаз ка нашим циљевима. Он неће уназадити људе већ ће 
лесног тела Европе у неколико наврата, Марк оцењује да је ратни сукоб последица старе наследне болести од које Европа жели да се излечи страшним крвопролићем: „Рат се води због прочишћења, и пролива се болесна крв.“ (Марк 1914 б) Уколико би будућа Европа требало да се исцели овом ужасном терапијом, стање у њој представља само део опште жеље за оздрављењем, и управо је из тог разлога рат свеобухватан: "Свет жели да се очисти, он жели рат. /.../ Народ /.../ зна да ће га рат прочистити.” (Марк 1914 г)

Марк одређује будућност здраве Европе као доба духа, ${ }^{7}$ осврћући се при томе и на сопствену улогу и доживљај рата: на бојном пољу, у непосредним ратним дејствима, пре свега у артиљеријским биткама, немачки уметник престаје да опажа непосредну околину и конкретне предмете и за њега се као битан састојак реалности (поново) јавља мистично и митско, легендарно и окултно - Зевс са својим громовима и Марс са невидљивим стрелама постају ратна свакодневица, ${ }^{8}$ која побуђује интуи-

очистити Европу, припремити је. / ... / Европа ради свом телу исто оно што и Француска свом током револуције. / . . / Наравно, често се бојим да ће се прилика у Европи поново пропустити! Да је поново прерано, велика крвна жртва. “(Марк 1914 6)

7 „Ја се не љутим због рата већ сам захвалан из дубине душе, није било другог прелаза у доба духа, Аугијеве штале, стара Европа могла је да буде очишћена само тако, да ли постоји иједна особа која жели овај рат престане? (Марк 1914 в) Ужасна искуства, међутим, Марка ће претворити у некога ко се нада да ће непријатељства брзо престати: «Данима гледам најужасније сцене које људски ум може да замисли... Остани смирена и не брини: вратићу ти се - рат ће се завршити ове године.» (Марк 1916 б) Рат се за немачког уметника трагично окончао два дана касније, погибијом код Вердена.

8 Окретање античком митско-митолошком наслеђу, упркос временској дистанци и разлици војних искустава, одликује и друге ствараоце у Првом светском рату, који посежу за жанровским памћењем хомерске епике, налазећи у њој скуп слика, метафора, 
цију дубље и више стварности. Захваљујући том осећају, за Марка стварно и материјално потпуно нестају. ${ }^{9}$

Са друге, источне стране Европе, почетак Првог светског рата се на различите начине огледа у стваралаштву руског будетљана, футуристе Владимира Мајаковског. ${ }^{10}$ У серији чланака у јесен 1914. Мајаковски

ликова и тропа - односно осећање заједничке егзистенцијалне или стварне ситуације - за распон осећања од величања рата и његових учесника до изражавања протеста због ужаса и бесмислености и оплакивања жртава. Посебан случај при томе чине енглески песници, учесници галипољске операције 1915-1916, који су се дословно нашли у „конкретизованом хронотопу“, крвавим ратним операцијама у непосредној близини Илиона, и, сходно томе, анахронизовали античко предање са тројанског бојишта. У можда и најпознатијој песми те врсте, насловљеној „Јутрос сам видео човека” Патрика Шо-Стујарта, лирски јунак, враћајући се на фронт развија паралелу између Ахилејеве и сопствене судбине: "Ахил је дошао у Троју / А ја у Херсонесе; / Кренуо је након гнева у бој, / А ја након три дана мира. // Да ли је толико тешко, Ахиле, / Толико тешко да се умре? / Ти знаш, ја, међутим, не - / Утолико сам ја срећнији. // Вратићу се овога јутра / Из Имброса преко мора. / Устани у рову, Ахиле, / Са пламен-шлемом, и поздрави ме ускликом.“ (Кендал 2013: 117)

9 „У сваком случају, рат ме није претворио у натуралисту; напротив, осећам дух који лебди у позадини битака, иза сваког метка, толико јако да стварно и материјално потпуно нестају. Битке, ране, покрети, изгледају толико мистично, нестварно, као да значе нешто сасвим супротно од својих назива: само што је све још увек страшно немо, загонетно, - или су, пак, моје уши заглухнуле, преплављене буком, тако да не могу да чују истински језик ових ствари данас. Невероватно је да су постојала времена у којима се рат представљао сликањем логорских ватри, села која горе, коњаника који јуришају, погођених коња или војника, и томе слично. Та ми идеја изгледа управо смешно, чак и када помислимо на Делакроа, који је био најбољи у томе. Учело је бољи. Египатски фризови су још бољи - но ми то морамо да учинимо прилично другачије, сасвим другачије! Када ће ми дозволити да поново сликам?" (Марк 1914 a)

10 Након избијања рата, Мајаковски узалудно настоји да ступи у војску; у почетку изузет из мобилизације као син јединац удо- 
пише о односу према рату, о стваралаштву и књижевности у ратно доба, показујући у својим размишљањима како одређене разлике тако и одређене сличности са западним уметницима у сличној ситуацији. За руског уметника рат тако не представља остварење програмског залагања већ се пре испуњење предосећаја и уметничке интуиције, при чему, поред његових сопствених, наглашава и слутње руског футуристе Велимира Хлебњикова. ${ }^{11}$ Рат, даље, представља позитивну силу, која неумитно доводи до побољшања друштвеног устројства, будући да је, по мишљењу Мајаковског, свако насиље корак ка савршенству, односно ка савршеној држави. (Мајаковски 1914) Такође, рат је узрок настанка нових колективних јунака, нове заједничке телесне и душевне снаге „свесног живота маса, чије ће тело, упркос безбројним мртвима, остати живо,“ (Мајаковски 1914 г) и описује се у естетским терминима - не као бесмислено убијање већ као песма која прославља ослобођену и уздигнуту колективну душу. ${ }^{12}$ На другом

вице, на крају ће, када је већ избледело одушевљење идејом одласка на фронт, ипак обући униформу, но неће вршити активну службу.

11 „Само размислите о свом бесу, о свим ужасима нашег постојања: десетак сањара живи, неком врстом ђаволске интуиције види да је данашњи предах само бесмислени доручак на складишту барута (пре свега, В. Хлебњиков, пре две године, он је црно на бело објавио да ће 1915. године људи поћи у рат и бити сведоци пропасти држава, док сам ја у својој трагедији прошле године, која је извођена у Петрограду у позоришту Комисаржевске, представио ту исту побуну ствари коју је данас приметио Велс)». (Мајаковски 1914 в)

12 „Историја је у последњем рату представила нову силу - свесни живот гомиле. Појаве стичу изузетну сразмеру. Ако једна особа једва зада ударац, међу хиљадама сличних она ће ударити силином огромне планине. Мозак, ширећи се, попут очију преплашене звери, навикнут је да преживи ранију неподношљиву катастрофу. Свест да је свака душа отворена за сјај ствара снагу, понос, са- 
месту, Мајаковски истиче да је рат показао да су академски професори и критичари заправо живи лешеви, недорасли изазовима тренутка - у ратно доба, које обнавља схватање поезије, песничка муза жели да се вози на артиљеријској кари у шеширу од пламеног наранџастог перја. (Мајаковски 1914 а) На крају, као "човек уметности", Мајаковски се пита да ли је рат "измишљен само да неко напише једну добру песму”. (Мајаковски 1914)

Поред исказивања општих ставова о узроцима, смислу и дометима сукоба, односно о уметничкој проблематици везаној за рат, ствараоци и сопственом вештином практично доприносе ратном напору, на фронту или у позадини. Спој њиховог умећа и непосредних задатака изражава се кроз бројне добровољне или задате активности, попут пропаганде, агитовања за подршку рату у људству и новцу, као и рада на осмишљавању и развијању камуфлаже. Сви наведени видови учешћа доводе до нарочите естетизације рата и ратних средстава, која ће у неким случајевима добити и сасвим конкретне облике.

Када је реч о добровољној пропагандистичкој активности, „Футуристичком синтезом рата“ („Sintesi Futurista della Guerra“), штампаном као летак у 20000 примерака и дељеном током новембра 1914. као под-

мољубље, осећај одговорности за сваки корак, свест да сваки живот равноправно улива крв у заједничке вене гомиле - осећај солидарности, осећај бесконачно повећање снаге снагама једнаких других.

Када пук крене у напад, у моћном «Ура» уопште се не може препознати чији глас припада Ивану, а у маси летећих смрти не можете рећи која је моја а која је онога другога. Смрт се обрушава на целу гомилу, али, немоћна, утиче на само мали део. Уосталом, наше заједничко тело остаје, тамо у рату сви ми истовремено дишемо, и стога је ту бесмртност.

Зато, из душе нове особе, свест је расла да рат није бесмислено убиство већ песма о ослобођеној и узвишеној души.“ (Мајаковски 1914 г) 
стицај за улазак Италије у рат, италијански футуристи настављају са провокативно-манифестним залагањем за међународни оружани сукоб, представљајући га као сучељавање футуристичких и пасеистичких снага. На летку, на страни будућности заступљени су „осам песника: Србија, Белгија, Француска, Русија, Енглеска, Црна Гора, Јапан, Италија“, док су на страни прошлости „академски критичари-педанти“ Немачка и Аустро-Угарска. Сукоб у који ће се Италија, самим тим и већина припадника футуристичког покрета, убрзо укључити, на прогласу се додатно одређује као естетички - право "италијанског стваралачког генија" да материјално разори класичну лепоту и изгради нову и већу. ${ }^{13}$

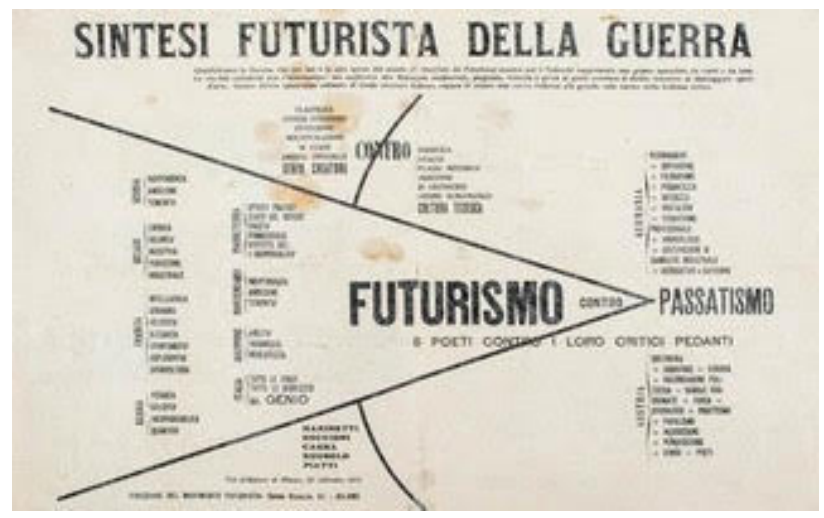

Футуристичка синтеза рата, 1914.

13 „Славимо рат, који за нас представља једино чишћење света (Први манифест футуризма), док за Немце представља масну гозбу за вране и хијене. Старе катедрале нису занимљиве; но, ми средњовековној, плагијаторској, и стваралачког генија лишеној Немачкој ускраћујемо футуристичко право да уништава уметничка дела. Ово право припада искључиво италијанском стваралачком генију, способном да створи нову и већу лепоту на рушевинама античке лепоте.

Маринети, Бочони, Кара, Русоло, Пјати - Милано, 20. септембра 1914.“"(Маринети 1914 а) 
Поред ове почетне верзије, пропагандни футуристички проглас-манифест појавиће се и у другој, незнатно измењеној, у књизи Карла Каре Ратосликарство (Guerrapittura, Кара 1915); малобројне промене носе танана померања у значењу и графичком обликовању: осам песника сада су осам «народа-песника», листи пасеиста додата је и Турска, као што је удвостручен и семантичко-графички елемент „против“.

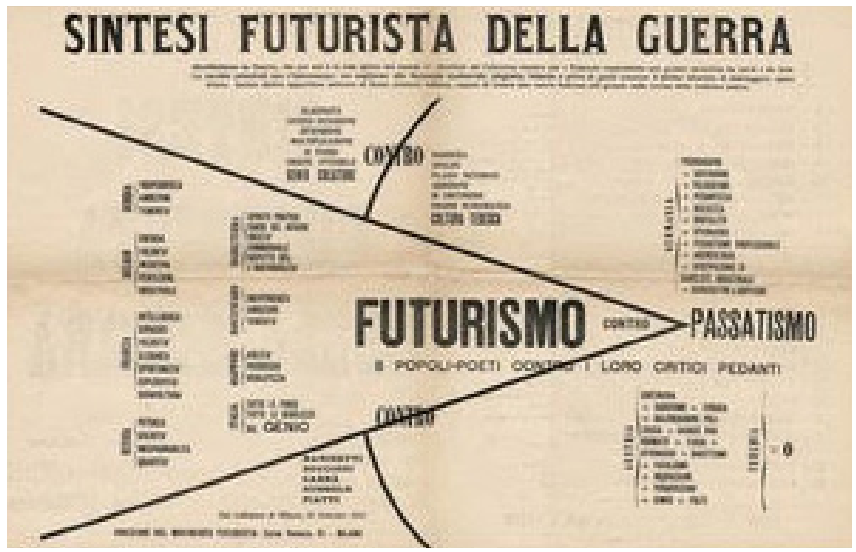

Футуристичка синтеза рата, 1915.

Футуристичка манифестна синтеза рата у својој трећој варијанти објављена је на самом крају непријатељстава, тачно четири године по објављивању прве (20.11.1918.). У складу са измењеним околностима и исходом, футуристи мењају бројне елементе, донекле их ублажавајући: наслов је другачији, и сада гласи „Синтеза светског рата“; уводни проглас је скраћен на једну реченицу која у овој верзији одређује рат не као борбу снага будућности против сила прошлости већ као револуцију за слободу; провокативно-деструктивни део о праву на разарање овде је изостављен; основна природа сукоба ретроактивно се види као борба слободе про- 
тив варварства, у којој учествују «сви“ народи-песници са осавремењене листе: на њу је додата Америка док су појединачне словенске нације сада обједињене под заједничком одредницом «Словени»; на страни варвара, поред Немачке, Аустро-Угарске и Турске, уврштена је и Бугарска, такође обележена нултим особинама. Из описа негативних аустријских особина избачен је папизам.

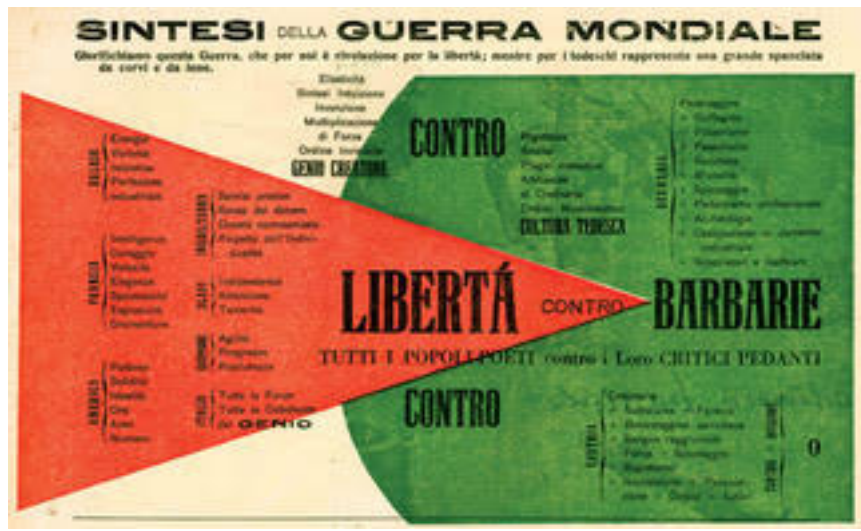

Синтеза светског рата, 1918.

Сродне ликовно-пропагандне активности могу се током рата запазити и код руских футуриста-авангардиста: њихов конкретни допринос на овом пољу огледа се у осмишљавању низа сирових, стриполиких ратних постера и разгледница са шаљивим римованим стиховима, урађених у духу традиције народне ликовне форме лубока. Од августа до октобра 1914. у сарадњи са издавачком кућом «Данашњи лубок» (Г. Б. Городецки, штампарија С. М. Мухарског), издат је низ „војних“ постера у боји, усмерених против ратних непријатеља Немачке, Турске и Аустро-Угарске. Као ликовни аутор већине плаката потписан је Казимир Маљевич, други, пак, сам Мајаковски, док су мањи број радова насликали Д. Д. Бурљук, В. Н. Чекригин, И. И. Машков и А. В. Лентулов. (Михаленко 2014: 294-295) 
Радови уметника «Данашњег лубока» руководили су се руском народном уметношћу, са једноставним ликовним изразом (пет чистих боја: жута, црна, црвена, зелена и црна, употребљених увек у истој нијанси) и јасном поетиком која је подразумевала спој стварних ситуација и композиционе технике старог војног лубока са нарочитом фолклорном поетиком приказивања битке: војници пробадају противнике својим оружјем, одсечене главе и удови разбацани су по бојном пољу, руски војник и жена из народа представљени су као снажни људи, односно као дивови. Честа мета изругивања је немачки цар Вилхелм, лишен императорског достојанства и изложен бритком хумору подругљивих стихова Мајаковског, као нпр. у постерима / разгледницама који је насликао Маљевич:

У Лођ је домао Кобасичар.

Рекли смо му: «Добар дан!»

Па је из Лођа, издеветан,

Отишао, сасвим сам.

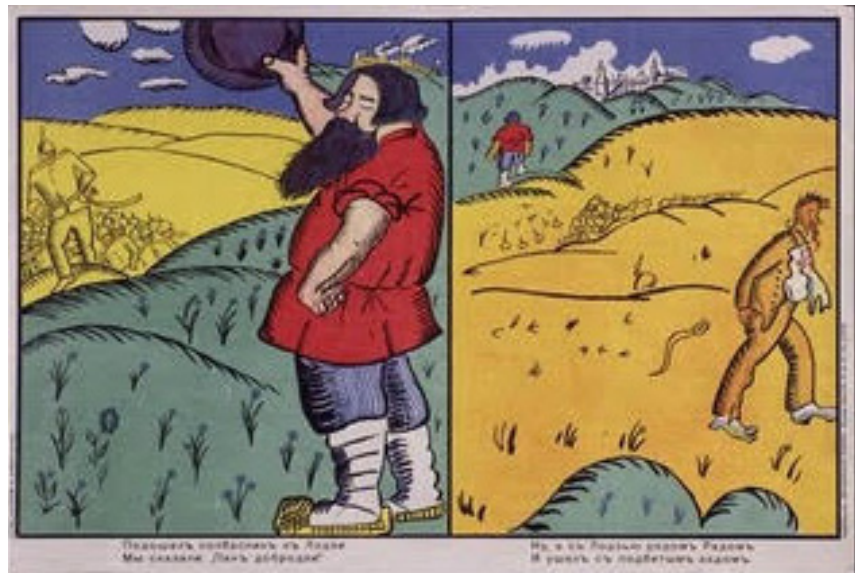

Лубок Мајаковског и Маљевича, 1914. 


\section{Односно:}

Испред тебе, мили Лублин-граде

Посечени непријатељь паде.

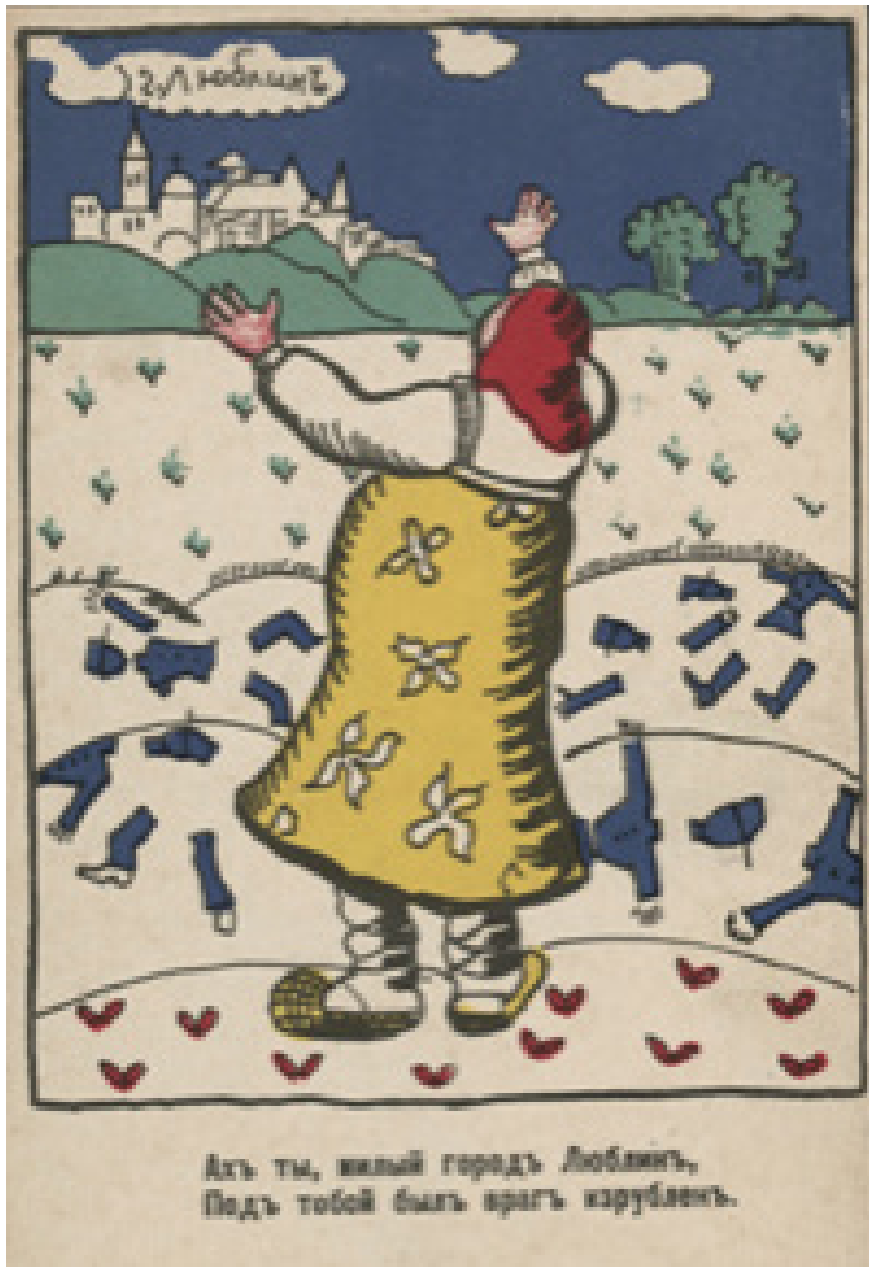

Лубок Мајаковског и Маљевича, 1914. 
Управо је хумор основа нарочитог споја пропагандног и естетичког у доприносу најмлађе, кинематографске, уметности ратном напору - једна од најпопуларнијих филмских звезда тога времена, Чарли Чаплин, током рата снимио је више пропагандних филмова, или је, хотимично или не, учествовао у њима. ${ }^{14}$ Још и пре конкретног филмског ангажмана, међутим, Чаплинови рани филмови и његова филмска персона, Мали Скитница, играли су велику, пре свега позитивну, улогу у свакодневном животу војника, подједнако у рововима и у позадини. ${ }^{15}$ У ратом захваћеној континенталној Европи, војници-уметници

14 Филм Чарли против иепелина (Zepped, 1916, изгубљен до 2009. односно 2011), који садржи једине познате документарне сцене напада немачких цепелина на Лондон, био је намењен подизању морала трупа у Египту и поништавању психолошког дејства честих ваздушних напада овим летелицама. Највероватније направљен без Чаплиновог учешћа, састављен од документарног материјала, различитих стоп-кадрова из неколико Чаплинових кратких филмова и анимираних делова, филм тематизује Чарлијев добровољни долазак Енглеску и успешну ваздушну борбу авионом против цепелина.

15 Сам Чаплин, британски држављанин који на раду у Холивуду, био је током рата под великим притиском јавности, пре свега енглеске, и проглашен „кривинашем“ јер није ступио у британску нити америчку војску. Послато му је на хиљаде белих пера (симбол кукавичлука) и љутитих писама како би се приволео да обуче униформу. На фронту, овај критички став добио је и уметнички облик - песма «Чарли Чаплин на блештавој месечини» («The Moon Shines Bright on Charlie Chaplin») првобитно је била негативно интонирана; током времена, међутим, преобразила се у популарну мелодију коју су подједнако певали и војници на положајима и цивили код куће, представљајући Чаплина као извор надахнућа и родољубља, симбол дома, слободног времена и ескапизма, обичног човека, једним од многих који су ушли у рат. На крају, име популарног комичара понео је тенк бр. 777, 8. чете Ц батаљона при 14. дивизији 7. корпуса 3. армије, смештен у околини Араса у Француској. 
се са Чаплиновим филмовима упознавали превасходно на одсуствима са фронта, и тај први додир оставио би толико снажан утисак, емоционални и естетски, да је за ствараоце друге и треће деценије прошлога века постао битан тренутак у животу, који је надвладао ратне ужасе тиме и пре свега незаобилазна аутобиографска тема. ${ }^{16}$ Осврћући се на војничке дане, Блез Сандрар, један од првих књижевника који ће нашироко тематизовати Чаплина, описујући ширење фаме о Чаплину на положајима ${ }^{17}$ непосредно повезује филмског уметника и исход рата, тврдећи да ако је Француска добила рат, то се догодило захваљујући вину, и Шарлу. ${ }^{18}$ Француски уметник Фернан Леже се са своје

16 Тако се једно од карактеристичних сусретања, према присећањима самог учесника, Андреа Салмона, одиграва 1916. године у Ници, у тренутку када је изнурени војник послат са линије фронта у град на опоравак. Током неовлашћеног изласка, у настојању да се спасе од „санитарних патрола“, књижевник-војник се након јурњаве по улицама скрива у биоскоп. Ту почиње пројекција за коју нема програм: најпре се дају италијански филмови препуни мелодраме и патетике, потом, ненадано: „И коначно се појави Шарло!“ (Салмон 1926: 242-243)

17 „Сећам се како се Шарлов углед ширио на фронту захваљујући онима који су дошли са допуста. Враћали су нам се зајапурени. Испитивали смо их. Препричавали су нам авантуре Шарла у мјузикхолу, Шарла боксера, Шарла који плови, Шарла који сели итд. Тако се смех ширио од рова до рова. То је највећа Шарлова слава, научио нас је да се смејемо, и нас и наше савезнике (Немачка га је видела тек дуго времена након примирја). У то доба још увек га нисам познавао, морао сам да чекам на свој ред на одсуство да га видим на платну (...)“. (Сандрар 1924: 78)

18 „Немци су изгубили рат јер нису упознали Шарла на време (након тога су га звали Карлхен или Август). Био сам у Риму 1920. године када су на Капитолу приказали првог Шарла. Италијани нису могли да воле Карлита будући да су се определили за Мусолинија. Русима Чаплин никада није био потребан, они су имали Лењина да их научи да се смеју.“ (Сандрар 1926: 234236). 
стране присећа околности и естетичког осећања новине у тренутку у коме је видео Чаплинова остварења: „Када сам једном приликом дошао са фронта на викенд, Аполинер ме је повео да видим Шарла. У то доба сматрало се да се оно што је битно догађа само 'тамо', да прави живот - на линији фронта и у позадини јесте искључиво гадост и смрт. Аполинер ми је рекао: 'Не, понешто се догађа и овде. Хајде, показаћу ти!' И видех Шарла. Утисак није био слабији од утиска који је остављао велики спектакл из кога сам се отргао на седам дана.“" (Леже 1926: 243-244)

Хумориста, илустратор и писац Пјер Анри Ками, од 1914. године мобилисан у састав француских Алпских ловаца, објављује у посебном издању хумористичког часописа Бајонет из 1917. године мултимедијални рад Шарло ратни дописник. Поред ратно-пропагандне, овај Камијев рад има и неспорну уметничку вредност - подељен је у девет „табли“, налик на сценарио неког Шарловог филма у коме се нижу фантастичне авантуре, почев од тренутка када, послуживши се лукавом варком, у чикашком листу добија место ратног дописника и путује преко океана за Европу, пловећи преко Атлантика налеће на немачку подморницу, завршавајући се његовим сусретом и интервјуом са (лажним) немачким владаром. Када је реч о визуелној страни садржаној у независном стрипу, Шарло ратни дописник отвара се илустрацијом у којој један наспрам другог, свако на свом престолу, седе са леве стране Шарло (држећи наместо штапа мали маљ), „цар филма“, а са десне Гијом (Вилхелм), „цар Немачке“. На крају, након бројних перипетија, Шарло немачком цару маљем забија круну у главу. (Ками 1917: 178; 189) 


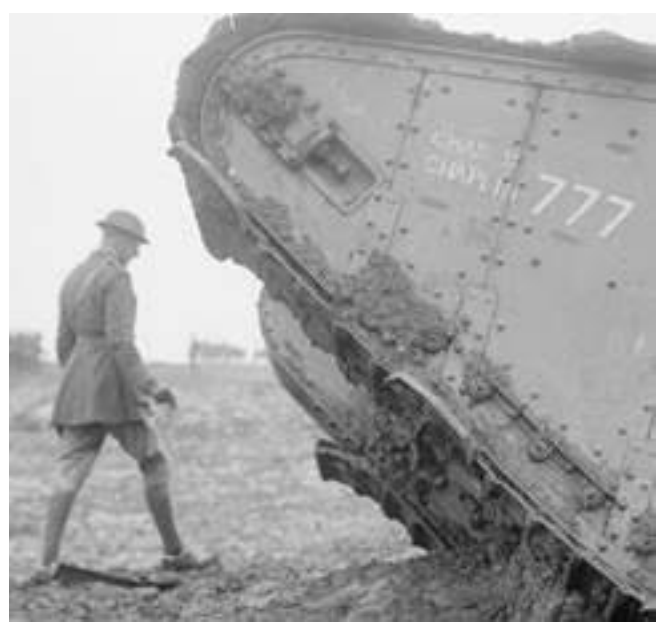

Тенк 777 "Чарли Чаплин"

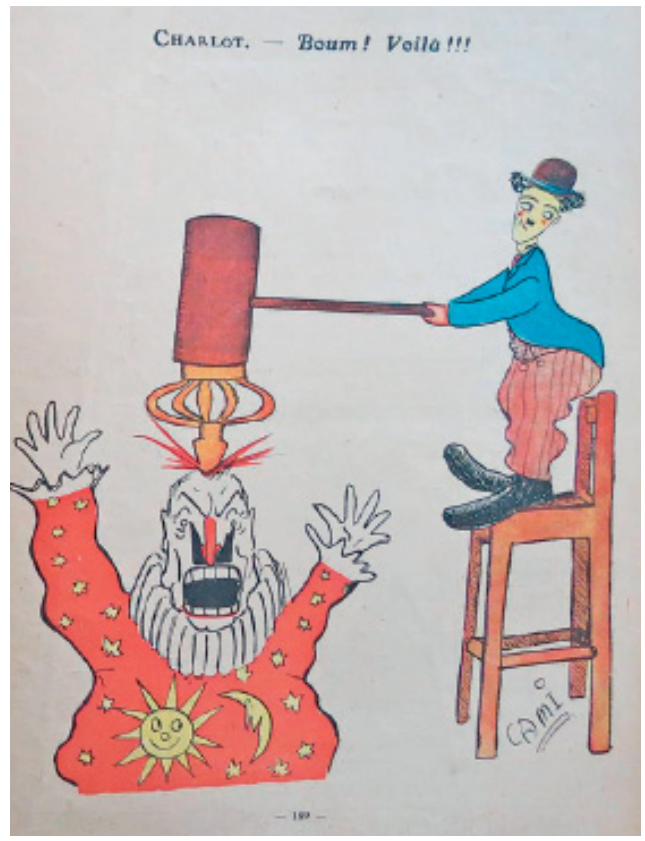

Пјер Анри Ками Шарло ратни дописник, 1917. 


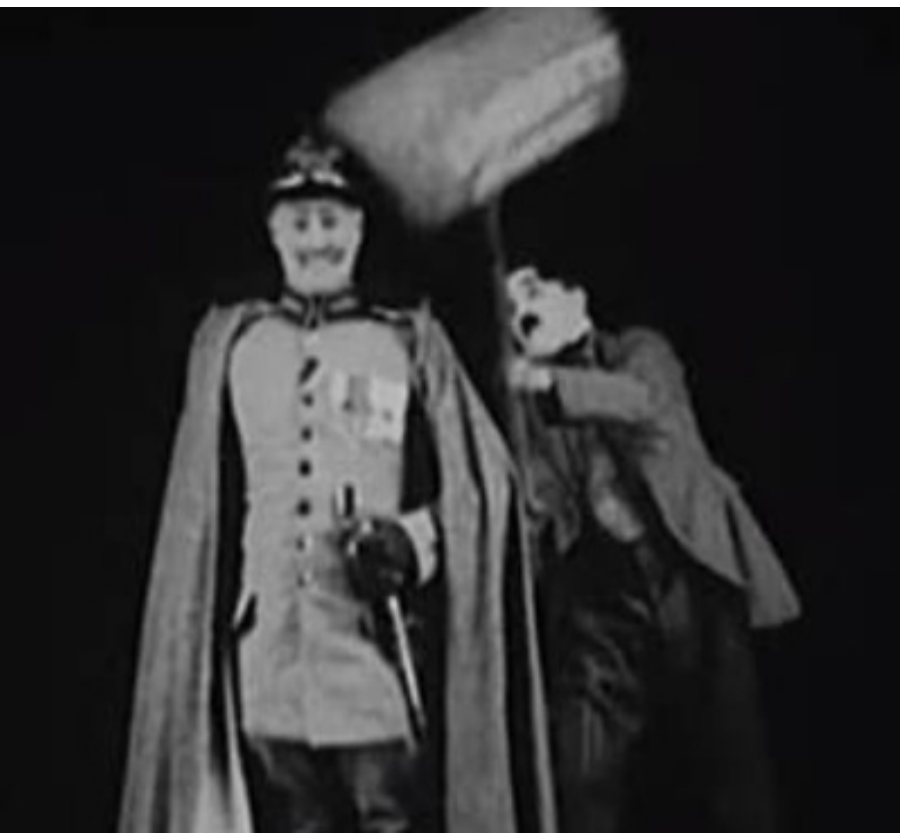

Чарли Чаплин Обвез(нии)a, 1918.

Истоветан мотив заступљен је и у првом Чаплиновом ауторском пропагандном филму The Bond («Обвеза / Обвезница») из 1918. године, ${ }^{19}$ у коме Скитница огромним маљем (на коме је исписано „Liberty bonds“) удара цара Вилхелма у главу, све док га не обори на земљу. На крају, једно од најуспелијих кинематографских дела која тематизују Велики рат, спајајући у себи пропагандну намену и високи естетски квалитет, на одлучујући је начин обележено хумором. Чаплинова визија у филму Пушку о раме (Shoulder Arms), првој, у великој мери црнохуморној, филмској ратној коме-

19 Изворно именован као Чарли Чаплин позива на Зајам за рат (Charles Chaplin in a Liberty Loan Appeal, види Геринг 2014: 57. 
дији, успешно је прожела дочаравање ужаса рововског рата (блато, гамад, влага, носталгија, непрестана смртна опасност од паљбе и од бојних отрова) са комичним елементима који припадају самим врхунцима жанра у настајању. При томе, нека од бурлескних претеривања и крајњих карикирања, попут секвенце са Чарлијем-извиђачем прерушеним у лажно, извиђачко дрво, спадају у антологијске сцене филмске уметности. ${ }^{20}$

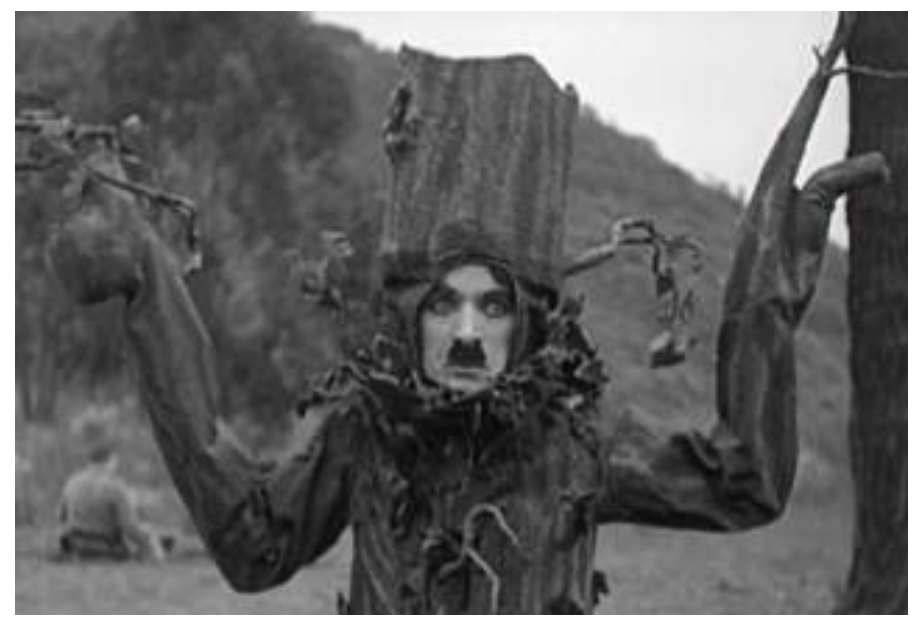

Чарли Чаплин Пушку о раме, 1918.

20 Види Венс 2003: 89. 


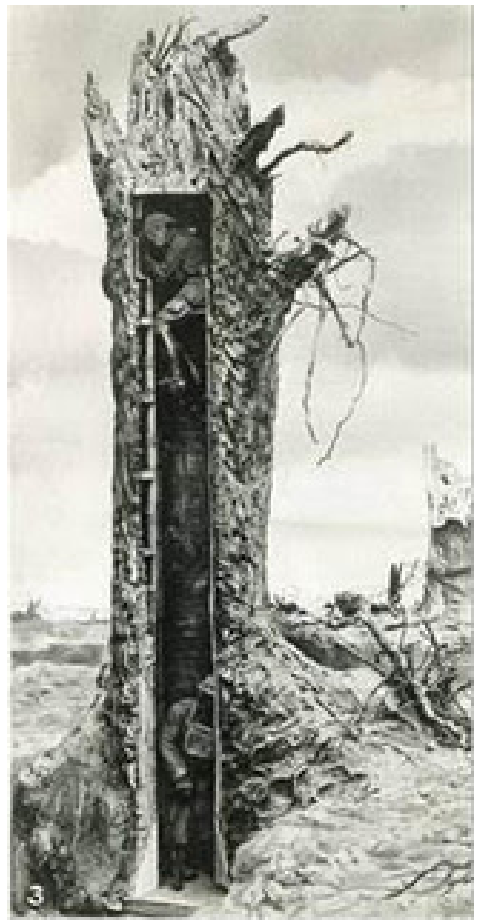

Вештачко дрво као извиђачко место

Један од радних наслова под којим је филм сниман - "Камуфлажа", (Геринг 2014: 59) речито сведочи о прожетости различитих видова уметности у Првом светском рату без преседана, ${ }^{21}$ будући да је нарочита врста примене ликовних вештина у ратним условима свој облик добила управо у настанку и развоју камуфлаже. Идеје о прикривању положаја, ратних оруђа, опреме и

21 Блез Сандрар са своје стране иде толико далеко да тврди да је Чаплин, када је правио филм Шарло као војник (Shoulder Arms снимљен док је Сандрар боравио на фронту у Европи) у одређеном степену био надахнут његовом фотографијом из рата, објављеном 1915. Сандрар 1971 : 95-96; види више у: Јамполски 1987 : 133. 
људства, односно удаљености, правца и брзине пловидбе бродова, проистекле су са једне стране из научних посматрања, ${ }^{22}$ са друге из уметничких размишљања и активности, ${ }^{23}$ везаних за природу опажања и настојања да се наруши уобичајена перцепција предмета.

Рад уметника на камуфлажи присутан је у свим великим армијама Првог светског рата. Методе прикривања изворно су развили «класични» сликари, декоратери или илустратори, да би се у њихово спровођење током времена укључили и уметници авангардних стремљења, чија се естетика показала пригодном за ратне потребе. ${ }^{24}$ У Француској, уметници који опслу-

22 Британски ембриолог Џон Грејем Кер, један од најранијих заговорника збуњивања чула на основу животињске камуфлаже, пише 1914. године у писму Черчилу: „Од суштинског је значаја да се разбије правилност обриса, а то се лако може остварити снажно контрастним нијансама. Исто важи за површину уопште - непрекидна једнообразна нијанса јесте упадљива. Ово се може променити разбијањем површине снажним контрастираним бојама. Жирафа или зебра или јагуар изгледају изузетно уочљиво у музеју, али у природи, када се не крећу, крајње их је тешко приметити, нарочито у сумрак. Исто начело треба користити у осликавању бродова.“" (Кер 1914: 177)

23 Везаних пре свега за поентилистичку технику наношења основних (плава, жута, црвена) и изведених боја (наранџаста, љубичаста, зелена) кратким потезима, како би се створила илузија целовитог облика.

24 Значајни представници авангарде у својим сећањима на ратно доба преувеличавају своју улогу у открићу и развитку камуфлаже. Описујући шетњу са шпанским сликаром булеваром Распај почетком рата у Паризу у модернистичкој „(ауто)биографији“ своје животне сапутнице Елис Токлас, Гертруда Стајн се присећа тренутка када су угледали први камуфлирани топ, и описује Пикасову реакцију и тврдњу да је то његова, тј. кубистичка заслуга: "Прве година рата, Пикасо и Ева, са којим је тада живио, Гертруда Стајн и ја, шетали смо низ булевар Распај у хладно зимско вече. Ништа на свету није хладније од Распаја у хладно зимско вече, ми смо то називали повлачењем 
жују артиљерију на различитим положајима, између осталих и сликар Гиран де Севола, сликар и декоратер Луј Гинго, позоришни сценограф Луј Берар, од самог почетка рата желе да прикрију топове, који сијају на сунцу и откривају положаје. Након успешне демонстрације маскирних поступака, који су подразумевали нарочито бојење, сакривање батерија гранама и церадама у шарама природе, као и прављење лажних оруђа и положаја, на лето 1915. године оснива се одељење за камуфлажу у француској армији.

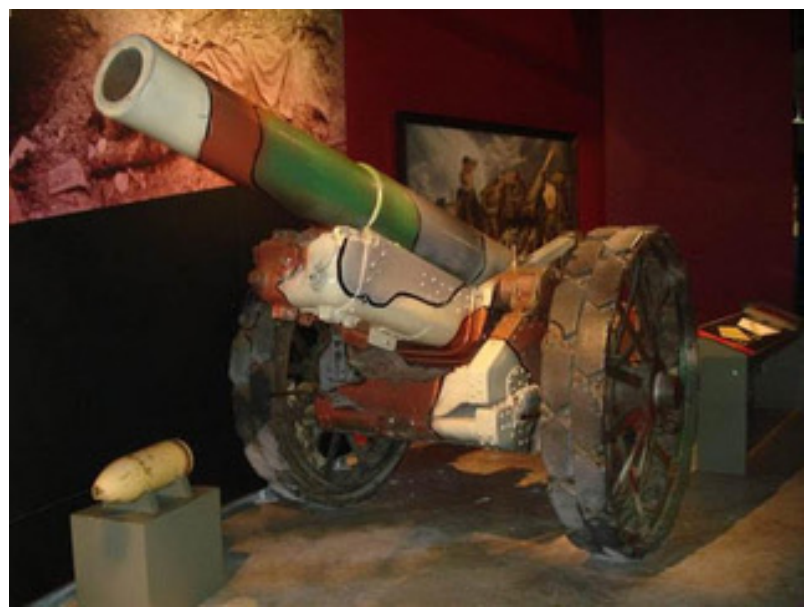

Енглеска хаубица у маскирним бојама

из Москве. Одједном је низ улицу дошао неки велики топ, први пут је било ко од нас видео осликани топ, то јест камуфлиран. Пабло се зауставио, био је као зачаран. C'est nous qui avons fait ça, рекао је, ми смо то створили, рекао је. И био је у праву, он је то створио. Од Сезана преко њега дошли су до тога. Његова предвиђања била су оправдана." (Стајн 1933) Коју годину касније, међутим, у књизи Стајнове о Пикасу чита се унеколико другачија верзија догађаја: "Била је ноћ, чули смо за камуфлажу али је нисмо видели и Пикасо је задивљено погледао камион и потом викнуо, да, ми смо то урадили, то јест кубизам." (Стајн 1938: 11). 
У немачкој војсци, Франц Марк исцртава маскирне шаре на церадама, у размишљањима их непосредно повезујући како са потребом стварања замућених, искривљених и збуњујућих слика које ће учинити положаје тешко видљивим за извиђање и фотографисање из ваздуха тако и са низом представника савременог сликарства. ${ }^{25}$ у исто време, швајцарски уметник немачког порекла, Паул Кле, додељен је јединици при аеродрому Обершлајсхајм, близу Минхена, са задатком супротним од Марковог - да прикупља оборене и покварене авионе по региону, и осликава их маскирним шарама. ${ }^{26}$

25 „Најдража, да си ме данас видела, свакако би посумњала у своје очи или у мој разум. Наишао сам на огромну појату (врло леп атеље!) и у њој насликао девет 'Кандинских’ на церадама. Овај посао је имао врло корисну сврху: да се артиљеријски положаји учине невидљивим за извиђачке авионе и снимање из ваздуха тако што ће се покрити церадним платном обојеним у грубо поентилистичком стилу и у складу са проучавањем боја природне камуфлаже (mimicry). Растојања са којима се рачуна јесу огромна, у просеку око 2000 метара - много ниже од тога непријатељски летач не силази. Фотографски снимци са те висине потом се јако увећавају, чиме се откривају угласте структуре заклона, складишта муниције покривена четвороугаоним церадама. Од сада, осликавање мора да створи у довољној мери замућену и искривљену збуњујућу слику како би положај био непрепознатљив. Дивизија ће нам доделити пилота да на основу фотографија проверимо изглед ствари из ваздуха. Веома сам заинтересован да видим како Кандински делују са две хиљаде метара. 9 церада образују развој 'од Монеа до Кандинског'“! (Марк 1916 a)

26 Значај оваквог приступа запажен је при анализи достигнућа немачке камуфлаже током Првог светског рата. „Једини одговор на извиђање из ваздуха је скривање одозго, или збуњивање тамо где је прикривање непрактично. Немачка, са њеним уобичајеним предвиђањем, и са свом енергијом и богатством, усредсредила се неколико година на начине којим би покорила своје суседе, није занемарила припреме, ма како огромне, за оно што је видела да постаје моћан чинилац њене стратегије. Док су савезници били присиљени да по потреби импровизују нека 


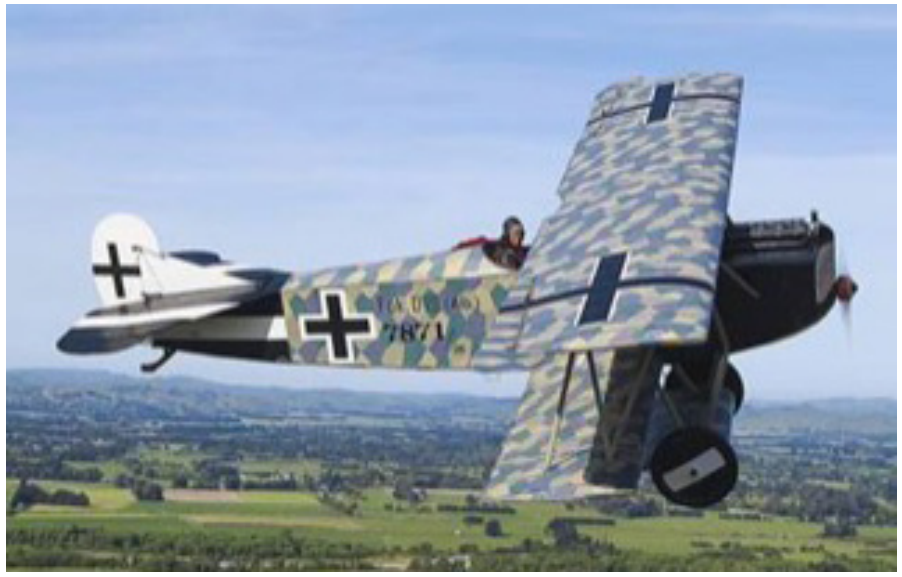

Маскирне шаре на немачком двокрилцу

Британски уметници дају први допринос ратној камуфлажи у осмишљавању и изградњи утврђених посматрачких места у облику дрвећа, које се везује за Соломона Џ. Соломона, члана Краљевске академије уметности. ${ }^{27}$ Соломон је доследно тврдио да камуфлажа представља „примену уметности у рату“ (Solomon 1920: vi) и подразумева изузетне уметничке способности, које укључују науку сенки и значење суптилних тонова, називајући је камуфлиране предмете „тлоцртима“ („ground-pictures“) са „постимпресионистичким

груба и шематска извиђања из ваздуха, Немачка, очигледно схватајући вредност у стратегији изненађења кроз прикривање свих могућих концентрација и активности на ширем фронту, већ је усавршила свој систем камуфлаже, на тако сналажљив, тако научан и тако прилагодљив начин, да је незамисливо да се такво савршенство може постићи без дугог експериментисања, пажљиво планиране организације и посебне дисциплине." (Соломон 1920: 2)

27 Соломон иде дотле да пореди савремене мајсторе камуфлаже и велике уметнике прошлости, попут Да Винчија, Микеланђела и Челинија. (Соломон 1920: 62) 
шарама“, и истичући да велики маскирни мајстор мора да поседује све одлике великог уметника - машту, индивидуалност и инвентивност (Соломон 1920 а: $453-$ 454).

Енглески уметници имали су одлучујућу улогу и у развоју друге врсте камуфлаже, усмерене не ка прикривању већ ка збуњивању чула - тзв. заслепљујућа / збуњујућа камуфлажа (енгл. dazzle painting, razzledazzle), ${ }^{28}$ тј. вишебојно маскирање, примењивала се превасходно на бродове, осликавањем шарама или испрекиданим (наизменичним, цик-цак) линијама. Оваквим начином бојења настојало се да отежа одређивање курса, брзине и врсте брода, са надом да ће то бити корисно нарочито против подморница.

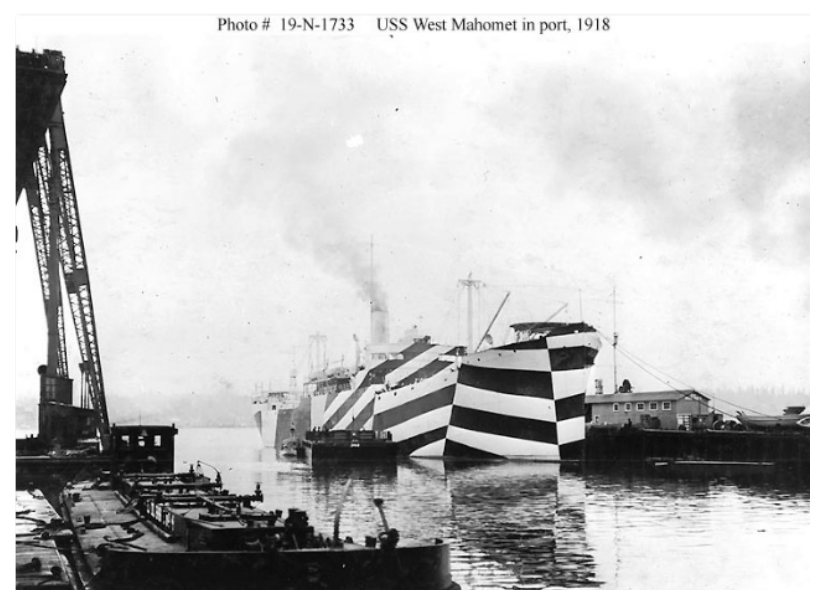

Амерички брод прекривен dazzle шарама

28 Развитак dazzle камуфлаже се обично везује за Нормана Вилкинсона, морнаричког официра и сликара; авангардни вортицистички уметник Едвард Вадсворт укључио се током рата у тим за dazzle камуфлажу, да би након престанка непријатељстава направио низ слика непосредно надахнутих искуством у бродоградилиштима Ливерпула. 


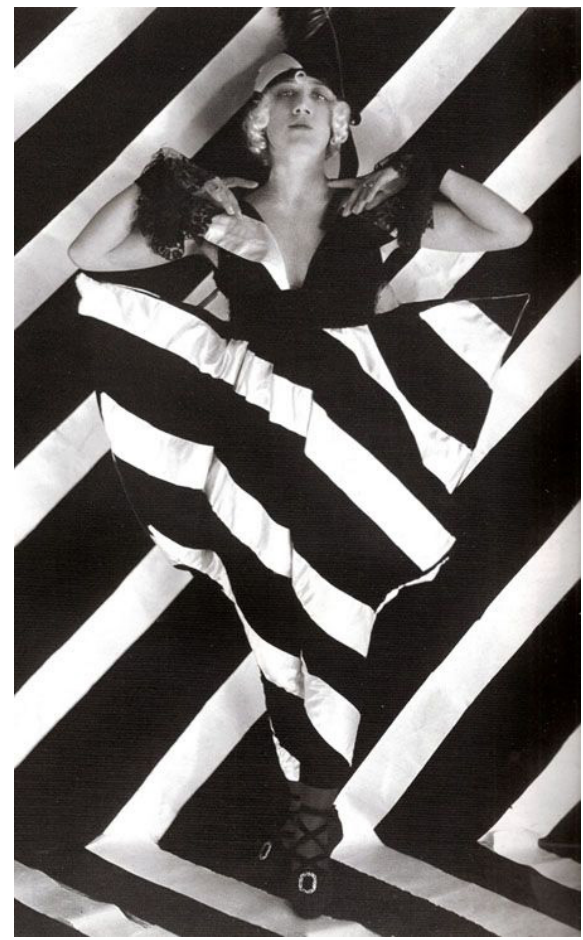

Модна примена dazzle камуфлаже

Иако се, међутим, испоставило да су немачки подморничари имали другачији нишански систем од онога који су Британци очекивали, те се тако ова врста камуфлаже показала као ограничено делотворна, њено дејство у области културе било је несумњиво: dazzle шаре појавиле и у свакодневној, комерцијалној, употреби, на смелим купаћим костимима, у модним линијама и апстрактним рекламама. (Фокс 2015: 80) Британски уметнички свет је пригрлио такав тренд: 1919. године Краљевска академија одржала је велику камуфлажну изложбу, док је Клуб уметности Челзи 1919 приредио костимирани уметнички бал на темy dazzle камуфлаже 
(Dazzle бал Клуба уметности Челзи, 12. марта 1919). ${ }^{29}$ Тако је уметност, ушавши у рат и прожевши се са непосредним војним задацима, направила пун круг, поневши са собом неке од конкретних војних примена и употребивши их у цивилном животу.

Незабележена концентрација писаца и уметника у Првом светком рату, на фронту или у позадини, имала је за последицу да се рат, осим тога што се наметнуо као тематски и формативни чинилац у „чистој“ књижевности и уметности, прожео са уметношћу и у многим мешовитим облицима. Тумачење сукоба као лековитог догађаја и поетичко-естетичке појаве у манифестима, писмима, дневничким записима и (поетичким) огледима, мешање античких јунака и богова са свакодневном ратном збиљом, пропагандна остварења несумњиве уметничке вредности која обнављају древне фолклорне обрасце, ликовни и уметнички преображаји непосредних војних елемената заједно са укључивањем комике и смеха као и увођењем новог медија који је препознао уметнички потенцијал ратне стварности - филма, само су неки од тих облика. Како било, кратак преглед прожимања естетског и војног током Првог светског рата, заснованог на различитим врстама проблематизовања (опажања) стварности и на посебним облицима укрштања уметничке вештине и практичних војних сврха, указује на чињеницу да је Велики рат по многим особинама био не само светски сукоб без преседана већ и јединствен културни и уметнички феномен.

29 Догађај, који је, као део поставке, укључио и огроман брод који је осликао сам Норман Вилкинсон био је уметнички догађај без преседана и вероватно полазна тачка за лондонске «луде двадесете». (Фокс, нав. дело). 


\section{ЛИТЕРАТУРА}

(Геринг 2014) Gehring, Wes D.. Chaplin's War Trilogy: An Evolving Lens in Three Dark Comedies, 1918-1947 /Kindle Location 1312/. McFarland \& Company, Inc., Publishers. Kindle Edition, 2014.

(Јамполски 1987) Iampolski, Mikhail. The Memory of Tiresias: Intertextuality and Film, University of California Press, Berkeley, 1998, стр. 133Léger, Fernand. Vivre Dans Le Vrai. Paris: Adrien Maeght, 1987, 74.

(Ками 1917) Cami, Pierre-Henri. La Baïonnette n92 du 22 Mars 1917

- Revue Spécial Charlot Correspondant de Guerre, 177-192.

(Kapa 1915) Carrà, Carlo. Guerrapittura. Milano: Edizioni Futuriste di "Poesia", 1915.

(Кендал 2013) Kendall, Tim. Poetry of the First World War: An Anthology. Oxford University Press, 10.10.2013, 312.

(Kep 1914) GUL, MS Gen 1302, 2, Kerr to Winston Churchill, 24 September 1914, John Graham Kerr - Protective Coloration of Ships, 2, y: Murphy, Hugh. Bellamy Martin. „The Dazzling Zoologist. John Graham Kerr and the Early Development of Ship Camouflage“, The Northern Mariner/le marin du nord, XIX No. 2, (April 2009), 171-192.

(Lеже 1926) Léger, Fernand. Le numéro spécial consacré à Charlie Chaplin des Chroniques $\partial d u$ jour, $n^{\circ} 7-8$, 7e année, 31 décembre 1926, str. 243-244.

(Мајаковски 1914 а) „Штатская шрапнель: Поэты на фугасах“. Утренний телебон газеть «Новь», М. 13 ноября 1914 г., № 3. (а)

(Мајаковски 1914 б) „Штатская шрапнель: Вравшим кистью“, Утренний телебон газеть «Новь», М. 14 ноября 1914 г. (б)

(Мајаковски 1914 в) „Теперь к Америкам!“, Газ. «Новь», М. 15 ноября 1914 г., № 115. (в)

(Мајаковски 1914 г) "Будетляне (Рождение будетлян)" Газ. «Новь», М. 14 декабря 1914 г., № 143., у: Маяковский, В. В. Полное собрание сочинений: 12 т. / Под общ. ... Т. 1. Стихи, поэмы, статьи, 1912-1917 / Ред. и комментарии Н. Харджиева, 1939, 59. (г) 
(Мајаковски 1914) Маяковский, Владимир. „Штатская шрапнель“, Утренний телебон газеть «Новь», М. 12 ноября 1914 г., № 2.

(Маринети 1909) Marinetti, F.T. "Manifeste du futurisme” (publié dans Le Figaro 55, 3, No 51, le 20 février 1909), 1.

(Маринети 1914) Marinetti, F.T."In quest'anno futurista”, Milano, 29. 11. 1914, 1-4

(Маринети 1915) Marinetti, F.T.“ Per la guerra, sola igiene del mondo", Milano, 1915.

(Марк 1914 а, 6, в) Marc Franz. Briefe. Schriften, Aufzeichnungen. Leipzig: Gustav Kiepenheuer 1989.

(Марк 1914 a) Brief an die Frau, (bei Schlettstadt) 12.IX. [19]14, стр. 102-103.

(Марк 1914 6) Brief an Wassily Kandinsky, Hagéville, 24.10.1914, стр. 203-204.

(Марк 1914 в) Postkarte an Wassily Kandinsky, 16.11.1914, стр. 205-206.

(Марк 1916 a) Brief an die Frau Marc 6.II.16, стр. 192.

(Марк 1916 6) Brief an die Frau Marc 2.III.16 стр. 200-201.

(Марк 1914 г) Marc, Franz. Das geheime Europa: Schriften. Köln: DuMont, 1978, стр. 162-167.

(Михаленко 2014) Михаленко, Наталья. „Военные лубки Владимира Маяковског и религиозные мотивы его раннего творчества“, у: Русский авангард и война, Редактор-составитель проф. д-р Корнелия Ичин, Филологический факультет, Белград 2014.

(Салмон 1926) Salmon, André. "Reconnaissance à Charlot," Dans le numéro spécial consacré à Charlie Chaplin des Chroniques du jour, $\mathrm{n}^{\circ} 7-8$, 7e année, 31 décembre 1926, 242-243.

(Сандрар 1924) Cendrars, Blaise. Le Disque Vert (2ème Année 5 numéros) nº 4-5, 1924, 78

(Сандрар 1926) Cendrars, Blaise. „La naissance de Charlot”, (1926) y: Aujourd'hui, Euvres complètes, Vol. 4, Paris: Denoël, 1962, 234-6.

(Сандрар 1971) Cendrars, Oeuvres complètes, Vol. 13, Le Club français du livre, Paris, 1971, 95-96.

(Соломон 1920) Solomon, Joseph Solomon. Strategic Camouflage, New York : E. P. Dutton and Company, 1920. 
(Стајн 1933) Stein, Gertrude. Autobiography of Alice B. Toklas, San Diego : Harcourt, 1933, http://gutenberg.net.au/ebooks06/ 0608711.txt

(Стајн 1938) Stein, Gertrude. Picasso, B. T. Batsford, London 1933.

(Фокс 2015) Fox, James. British Art and the First World War, 1914-1924. Cambridge University Press, 2015.

Bojan JOVIĆ

\section{THE FIRST WORLD WAR - SOME AESTHETIC AND POETIC ASPECTS}

Summary: The text will show some of the most striking examples of interweaving and permeation of poetic, aesthetic, ideological and political principles with direct military activities, embodied in the creation and operation of prominent writers and artists during the First World War. The attention is dedicated to the relation to reality, first of all to the destruction, concealment and (re)formation of its assumptions, from the prevailing artistic stance that the war will bring to death a sick civilization from the beginning of the XX century, through the creation of hybrid works of propaganda and art, to the direct application of painting techniques in the creation and development of camouflage. In the end, the role of Charlie Chaplin in the war effort will be considered, his films with aesthetic bringing along a dimension of humor and laughter in the treatment of war subject.

Keywords: The Great War, aesthetics, avant-garde, manifesto, camouflage, Charlie Chaplin 